\title{
AKTIVITAS ANTIBAKTERI FILTRAT Streptomyces sp. KCM2 TERHADAP MULTIDRUG RESISTANT Acinetobacter baumannii SECARA IN VITRO
}

\author{
IN VITRO ANTIBACTERIAL ACTIVITY OF Streptomyces sp. KCM2 FILTRATE AGAINTS \\ MULTIDRUG RESISTANT Acinetobacter baumannii
}

\author{
NI KADEK LOSIANI ${ }^{*}$, RETNO KAWURI, A. A. KETUT DARMADI \\ Program Studi Biologi FMIPA Udayana, Kampus Bukit Jimbaran - Bali \\ *Email: Losi_potter@yahoo.co.id
}

Naskah diterima 21 Juni 2016, Naskah disetujui 17 April 2017

\section{INTISARI}

Acinetobacter baumannii merupakan salah satu patogen yang sudah mengarah ke multidrug resistant (MDR-A baumannii). Patogen ini sering menjadi penyebab wabah infeksi pada pasien yang mendapat perawatan di ruang rawat intensif di rumah sakit. Penelitian ini bertujuan untuk mengetahui aktivitas antibakteri dan Minimum Inhibitory Concentration (MIC) filtrat Streptomyces sp. KCM2 terhadap pertumbuhan MDR-A baumannii secara in vitro. Isolat Streptomyces sp. KCM2 telah diisolasi pada rizosfer tanaman kunyit putih (Curcuma mangga Val.) (Losiani et al., 2016). Isolat MDR-A. baumannii diperoleh dari stock culture Laboratorium Mikrobiologi Klinik RSUP Sanglah Denpasar. Uji antibakteri dan uji MIC filtrat Streptomyces sp. KCM2 terhadap pertumbuhan MDRA. baumannii menggunakan metode sumur difusi. Rancangan penelitian yang digunakan adalah Rancangan Acak Lengkap (RAL) dan data diameter zona hambat uji MIC dianalisis dengan Analysis of Varian (ANOVA) kemudian dilanjutkan dengan uji Duncan Multiple Range Test taraf signifikan 5\%. Hasil penelitian menunjukkan bahwa filtrat Streptomyces sp. KCM2 mampu menghambat dengan diameter zona hambat sebesar 23,44 mm dan MIC filtratnya adalah $4 \%(\mathrm{v} / \mathrm{v})$ dengan diameter zona hambat $8,77 \mathrm{~mm}$.

Kata kunci: Antibakteri, filtrat Streptomyces sp. KCM2, MDR-Acinetobacter baumannii

\begin{abstract}
Acinetobacter baumannii is one of the pathogen which leads to multidrug resistant (MDR-A baumannii). This pathogen is often causing outbreaks of infections to the patients which are receiving treatment in the intensive care unit in hospital. This study aims to find out the antibacterial activity and the Minimum Inhibitory Concentration (MIC) of Streptomyces sp. KCM2 filtrate in inhibiting the growth of MDR-A baumannii. Streptomyces sp. KCM2 isolates was isolated in rhizosphere of white turmeric (Curcuma mango Val.) (Losiani et al., 2016). MDRA. baumannii isolates were obtained from stock culture in Clinical Microbiology Laboratory Sanglah Hospital in Denpasar. The antibacterial and the MIC test of Streptomyces sp. KCM2 filtrate was using the wells diffusion method. The research design was used Completely Randomized Design (CRD) and the inhibitory zone diameter data of MIC test were analyzed by Analysis of Varian (ANOVA), and then continued by Duncan Multiple Range Test in significance level 5\%. The results of this study showed that the Streptomyces sp. KCM2 filtrate was able inhibiting with diameter zone of $23,44 \mathrm{~mm}$ and MIC of filtrate was $4 \%(\mathrm{v} / \mathrm{v})$ with inhibition zone diameter of $8.77 \mathrm{~mm}$.
\end{abstract}

Keywords: Antibacterial, Streptomyces sp. KCM2 filtrate, MDR-Acinetobacter baumannii

\section{PENDAHULUAN}

Antibiotik pertama kali digunakan untuk mengobati infeksi serius pada tahun 1940-an. Sejak tahun itulah antibiotik menjadi penyelamat jutaan nyawa, namun selama 70 tahun terakhir bakteri telah menunjukkan kemampuan untuk menjadi resisten terhadap setiap antibiotik yang telah dikembangkan (Saga and Yamaguchi, 2009). Bakteri resisten merupakan bakteri yang tidak dapat dikendalikan atau dibunuh dengan antibiotik karena bakteri tersebut terus menerus mengalami perubahan antigenik untuk melawan kekebalan tubuh pasien dan terapi antibiotik. Salah satu bakteri patogen yang resisten terhadap beberapa antibiotik adalah Acinetobacter baumannii (Bou et al., 2000).

Bakteri A. baumannii resisten diakui sebagai salah satu bakteri aerobik golongan Gram negatif yang tahan terhadap beberapa antibiotik yaitu ampisillin, ceftazi- 
dime, meropenem, levofloxacin, amikacin, dan trimethoprim-sulfamethoxazole (Cucuwaningsih et al., 2015). Bakteri A. baumannii resisten ini diketahui memiliki spektrum klinis yang luas seperti bakteremia, pneumonia, meningitis, infeksi saluran kemih, infeksi kulit dan jaringan lunak, infeksi aliran darah, endokarditis, abses intra abdominal, dan infeksi luka operasi (Howard et al., 2010). Munoz and Weinstein (2008), mengatakan bahwa $A$. baumannii menjadi perhatian utama karena sudah mengarah ke Multidrug Resistant A. baumannii (MDR-A. baumannii).

Antibiotik memiliki sifat intrinsik yang tidak bergantung pada ukuran dan jumlah materinya, oleh karena itu resistensi terhadap mikroba target dapat muncul sehingga antibiotik ini tidak lagi efektif untuk pengobatan (Saga and Yamaguchi, 2009). Berkaitan dengan hal tersebut, maka perlu dilakukan penemuan-penemuan antibiotik baru baik secara sintesis kimia, biokimia, atau melalui isolat mikroba baru (Chopra et al., 2002). Isolasi antibiotik sebelumnya sudah banyak dilakukan pada galurgalur mikroba dan sudah banyak diujikan pada beberapa bakteri patogen. Potensi besar penghasil antibiotik salah satunya dimiliki oleh bakteri Streptomyces sp. Bakteri Streptomyces berkontribusi dalam memproduksi antibiotik sebanyak 70\%, sedangkan sisanya sekitar 20\% dihasilkan oleh jamur, dan 10\% dihasilkan oleh bakteri lain (Omura et al., 2001). Senyawa bioaktif metabolit sekunder yang dapat dihasilkan oleh Streptomyces sp. adalah antijamur, antivirus, antitumoral, antihipertensi, imunosupresan, dan antibiotik.

Penelitian ini bertujuan untuk mengetahui aktivitas antibakteri dan Minimum Inhibitory Concentration (MIC) filtrat Streptomyces sp. KCM2 terhadap pertumbuhan MDR-A baumannii secara in vitro.

\section{MATERI DAN METODE}

Isolat Streptomyces sp. KCM2 telah diisolasi oleh Losiani et al. (2016) (Gambar 1) pada rizosfer tanaman kunyit putih (Curcuma mangga Val.). Isolat Multidrug Resistant Acinetobacter baumannii (MDR-A. baumannii) yang resisten terhadap 12 jenis antibiotik yaitu antibiotik ampisillin, cefazolin, ceftazidime, ceftriaxone, cefepime, aztreonam, amikacin, gentamisin, ciprofolxacin, nitrofurantoin, Ampisillin/sulbaktam, piperasillin/ tazobaktam, dan trimethoprim/sulfamethoxazole, diperoleh dari stock culture Laboratorium Mikrobiologi Klinik RSUP Sanglah. Uji antibakteri dan penentuan Minimum Inhibitory Concentration (MIC) filtrat Streptomyces sp. KCM2 terhadap MDR-A. Baumannii secara in vitro dilaksanakan di Laboratorium Mikrobiologi Jurusan Biologi Fakultas Matematika dan Ilmu Pengetahuan Alam Universitas Udayana.

Koloni Streptomyces sp. KCM2 usia 5 hari yang ditanam pada media YMA/ISP 4 diambil dengan menggunakan cork borer ukuran $5 \mathrm{~mm}$ kemudian dipindahkan ke media YMB (Yeast Malt Broth) sebanyak $100 \mathrm{~mL}$.

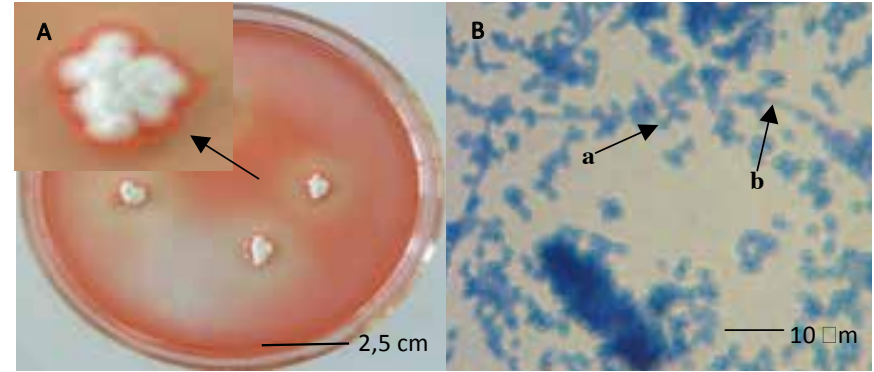

Gambar 1. (A) Koloni Streptomyces sp. KCM2 usia 5 hari pada media YMA/ISP 4 dan (B) Struktur mikroskopis (a. konidia dan b. hifa). Perbesaran $1.000 \mathrm{x}$ dengan Mikroskop Cahaya (merk: Yazumi) (Losiani et al., 2016)

Kultur Streptomyces sp. diinkubasi selama 14 hari pada shaker berbalasan dengan kecepatan 70 rpm. Selanjutnya di sentrifugasi dengan kecepatan 11.000 rpm selama 15 menit untuk mendapatkan bagian supernatan dan pelet. Kultur disaring dengan menggunakan kertas saring ukuran 0,45 $\mu \mathrm{m}$ untuk mendapatkan filtratnya dan bagian residunya dibuang (Ramazani et al., 2013).

Filtrat yang diperoleh selanjutnya dipartisi yaitu dengan memasukkan filtrat sebanyak $100 \mathrm{~mL}$ ke dalam labu pemisah ukuran $250 \mathrm{~mL}$ dan ditambahkan pelarut nbutanol sebanyak $100 \mathrm{~mL}$ sehingga perbandingannya 1:1 (v/v). Kedua larutan tersebut dihomogenkan dan didiamkan selama 24 jam hingga fase air dan fase n-butanol terpisah. Masing - masing fase tersebut dipisahkan dengan menggunakan corong pemisah dan dievaporasi menggunakan mesin evaporator dan pada suhu $40^{\circ} \mathrm{C}$ hingga konsentrasi menjadi sebanyak $\pm 10 \mathrm{~mL}$. Hasil tersebut selanjutnya diuji secara in vitro terhadap MDRA. baumannii dengan metode sumur difusi (Kawuri, 2012).

Uji aktivitas antibakteri filtrat dilakukan dengan memasukkan suspensi MDR-A. baumannii usia 24 jam dengan kerapatan $1 \times 10^{8} \mathrm{sel} / \mathrm{mL}$ ke dalam cawan Petri sebanyak $200 \mu \mathrm{L}$ dan dituangkan media NA sebanyak $10 \mathrm{~mL}$ lalu dihomogenkan dan dibiarkan hingga memadat. Setelah media memadat, pada bagian tengah media dibuat sumur difusi dengan cork borer ukuran $5 \mathrm{~mm}$. Selanjutnya, filtrat Streptomyces sp. KCM2 yang diisolasi pada fase air dan fase n-butanol dimasukkan sebanyak $20 \mu \mathrm{L}$ ke dalam sumur difusi tersebut, kemudian diinkubasi selama $24-48$ jam pada suhu $28^{\circ} \mathrm{C}$. Setelah inkubasi, diameter zona hambat yang dihasilkan oleh filtrat Streptomyces sp. KCM2 diukur.

Uji MIC dilakukan dengan menggunakan metode sumur difusi dengan beberapa persentase filtrat (v/v) yaitu 100\%, 90\%, 80\%, 70\%, 60\%, 50\%, 40\%, 30\%, 20\%, 10\%, dan n-butanol sebagai kontrol negatif serta antibiotik tigesiklin sebagai kontrol positif yang memiliki MIC $1 \mu \mathrm{g} / \mathrm{mL}(\mathrm{b} / \mathrm{v})$. Antibiotik tigesiklin digunakan sebagai kontrol positif karena MDR-A. Baumannii yang diperoleh dari Laboratorium Mikrobiologi Klinik RSUP Sanglah masih sensitif terhadap antibiotik tersebut. 
Masing-masing konsentrasi filtrat dibuat dalam 3 kali ulangan dan diinkubasi pada suhu $28^{\circ} \mathrm{C}$ selama $24-48$ jam. Zona hambat yang terbentuk diamati dan diukur. Selanjutnya persentase filtrat terendah yaitu 10\% yang masih mampu menghambat diturunkan lagi persentase filtratnya hingga $1 \%$.

Pengolahan data dilakukan secara kuantitatif yaitu dengan menghitung zona hambat yang terbentuk dari uji MIC filtrat Streptomyces sp. KCM2 terhadap MDRA. baumannii dengan menggunakan Analysis of Varian (ANOVA) dan dilanjutkan dengan uji Duncan Multiple Range Test taraf signifikan 5\% karena hasil ANOVA menunjukkan hasil yang signifikan.

\section{HASIL}

Filtrat Streptomyces sp. KCM2 yang terisolasi pada hari inkubasi ke-14 pada media YMB (Yeast Malt Broth) berwarna kuning kecoklatan (Gambar 2).

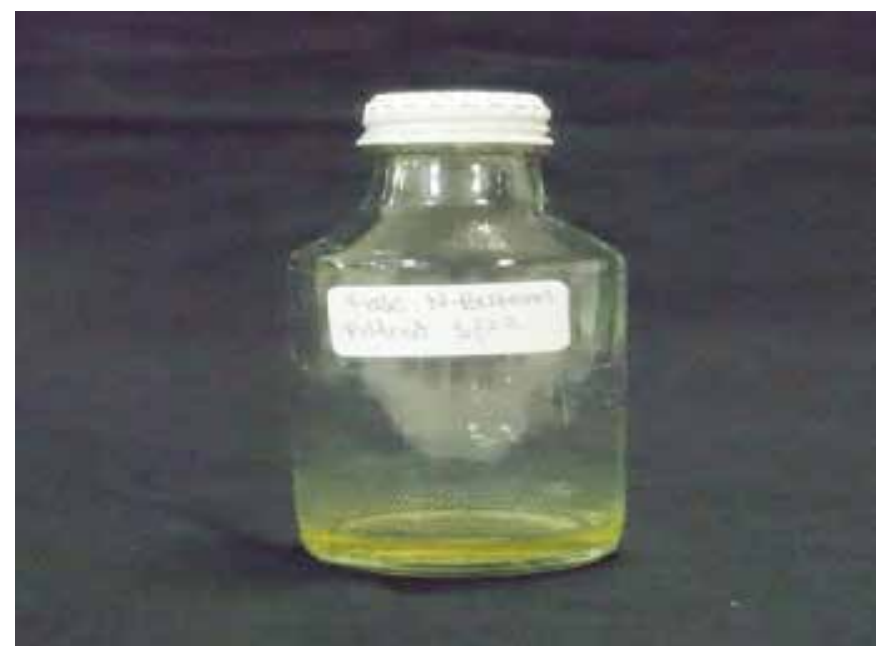

Gambar 2. Filtat Streptomyces sp. KCM2 pada fase n-butanol

Hasil uji aktifitas filtrat Streptomyces sp. KCM2 terhadap MDR- A. baumannii menunjukkan bahwa filtrat yang mampu menghambat bakteri uji adalah filtrat pada fase n-butanol dengan diameter zona hambat sebesar 23,44 $\mathrm{mm}$, sedangkan pada fase air tidak menghasilkan hambatan (Gambar 3). Setelah diuji, diketahui bahwa MIC filtrat Streptomyces sp. KCM2 terhadap pertumbuhan MDR-A. baumannii adalah 4\% (v/v) dengan diameter hambat $8,77 \mathrm{~mm}$ (Tabel 1).

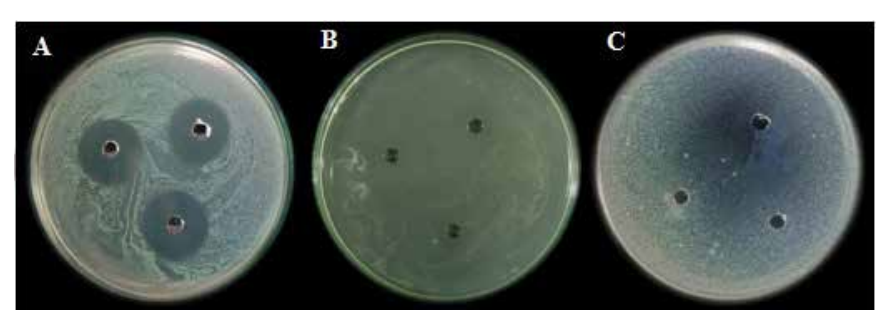

Gambar 3. (A) Daya hambat filtrat Streptomyces sp. KCM2 pada fase n-butanol; (B) Daya hambat filtrat Streptomyces sp. KCM2 pada fase air; dan (C) Kontrol n-butanol
Tabel 1. Hasil uji MIC filtrat Streptomyces sp. KCM2 dengan konsentrasi $100 \%-1 \%(\mathrm{v} / \mathrm{v})$ terhadap multidrug resistant Acinetobacter baumannii

\begin{tabular}{|c|c|}
\hline Konsentrasi Filtrat & Diameter Zona Hambat (mm) \\
\hline $100 \%$ & $23,44 \pm 0,12^{j}$ \\
\hline $90 \%$ & $23,24 \pm 0,38^{j}$ \\
\hline $80 \%$ & $23,05 \pm 0,17^{j}$ \\
\hline $70 \%$ & $21,00 \pm 0,30^{i}$ \\
\hline $60 \%$ & $20,49 \pm 0,04^{h}$ \\
\hline $50 \%$ & $19,02 \pm 0,29^{g}$ \\
\hline $40 \%$ & $17,98 \pm 0,72^{f}$ \\
\hline $30 \%$ & $16,86 \pm 0,17^{\mathrm{e}}$ \\
\hline $20 \%$ & $12,19 \pm 0,33^{d}$ \\
\hline $10 \%$ & $10,44 \pm 0,38^{c}$ \\
\hline $9 \%$ & $10,38 \pm 0,34^{c}$ \\
\hline $8 \%$ & $10,16 \pm 0,28^{c}$ \\
\hline $7 \%$ & $9,99 \pm 0,08^{c}$ \\
\hline $6 \%$ & $9,72 \pm 0,42^{c}$ \\
\hline $5 \%$ & $9,66 \pm 0,70^{c}$ \\
\hline $4 \%$ & $8,77 \pm 0,69 b$ \\
\hline $3 \%$ & $0,00 \pm 0,00^{a}$ \\
\hline $2 \%$ & $0,00 \pm 0,00^{a}$ \\
\hline $1 \%$ & $0,00 \pm 0,00^{a}$ \\
\hline $\begin{array}{c}\text { Kontrol }+\underset{\mu \mathrm{g} / \mathrm{mL})}{\text { (Tigecycline MIC } 1} \\
\text { (1) }\end{array}$ & $21,91 \pm 0,38^{i}$ \\
\hline Kontrol - (n-butanol) & $0,00 \pm 0,00^{a}$ \\
\hline
\end{tabular}

Keterangan: Nilai-nilai pada tabel merupakan rata-rata dari tiga kali ulangan \pm standar deviasi. Nilai yang diikuti oleh huruf yang sama pada suatu kolom merupakan nilai rata-rata yang tidak berbeda nyata $(P>0,05)$ berdasarkan uji Duncan Multiple Range Test taraf signifikan $5 \%$

\section{PEMBAHASAN}

Filtrat pada fase n-butanol mampu membentuk zona hambat dikarenakan senyawa bioaktif yang dihasilkan oleh Streptomyces sp. KCM2 terikat pada pelarut nbutanol yang bersifat semipolar. Apabila dibandingkan dengan kontrol n-butanol yang tidak menghambat, maka daya hambat yang terbentuk pada fase n-butanol disebabkan oleh senyawa bioaktif yang dihasilkan oleh Streptomyces sp. KCM2 bukan disebabkan oleh n-butanol. Hal tersebut didukung oleh pernyataan Bouras et al. (2013), bahwa pelarut n-butanol merupakan pelarut organik yang paling baik untuk isolasi antibiotik. Hasil penelitiannya menunjukkan bahwa kemampuan menghambat filtrat Streptomyces sp. PP14 terhadap B. subtilis ATCC 6633 dan Mucor ramannianus NRRL 1829 paling besar dihasilkan oleh filtrat pada pelarut n-butanol dibandingkan dengan etil asetat dan diklorometan.

Selanjutnya untuk mengisolasi antibiotik dari Streptomyces sp. perlu memperhatikan waktu inkubasi karena hal tersebut berkaitan dengan produksi metabolit sekunder terutama aktivitas antimikrobanya. Waktu inkubasi yang digunakan untuk mengisolasi Filtrat Streptomyces sp. KCM2 adalah 14 hari. Mengacu pada pene- 
litian Ramazani et al. (2013), bahwa filtrat Streptomyces sp. yang diinkubasi selama 14 hari mampu menghambat pertumbuhan E. coli, S. typhimurium, S. aureus dan Pseudomonas aeruginosa. Penelitian lain dilakukan oleh Lertcanawanichakul et al. (2015), menyatakan bahwa Streptomyces lydicus A2 mampu menghambat pertumbuhan $S$. aureus, $B$. subtilis dan $S$. typhimurium dengan filtrat yang diinkubasi selama 12 hari.

Menurut Lertcanawanichakul et al. (2015), beberapa metabolit sekunder disintesis tidak pada waktu yang sama dan tidak pada semua waktu inkubasi, walaupun saat inkubasi diberi kondisi yang sama. Oleh karena itu, senyawa bioaktif dapat diisolasi pada waktu inkubasi yang beragam. Seperti pada penelitian Bouras et al. (2013), bahwa filtrat Streptomyces sp. PP14 yang diinkubasi selama 10 hari juga mampu menghambat beberapa bakteri Gram positif, bakteri Gram negatif, yeast, dan beberapa fungi. Selain itu, Susilowati dkk. (2007), melaporkan bahwa Streptomyces sp. A3.5 yang diinkubasi selama 3 hari mampu menghambat Burkholderia pseudomallei 0205 dan setelah 3 hari ternyata kemampuan filtrat mengalami penurunan. Namun Streptomyces F6.1 yang diinkubasi selama 4 hari mampu menghambat E. coli K1.1.

Kemampuan menghambat yang ditunjukkan oleh Streptomyces sp. KCM2 menandakan adanya senyawa bioaktif yang dihasilkan. Akintunde (2014), dalam penelitiannya mengatakan bahwa, 2 senyawa bioaktif yang belum diketahui jenisnya telah terdeteksi pada filtrat Streptomyces sp. COUK1 yang memiliki daya hambat terhadap E. coli, Micrococcus luteus, dan Rhodococcus erytrhopolis. Barrios-Gonzalez et al. (2003), melaporkan bahwa Streptomyces spp. merupakan bakteri yang mampu memproduksi antibiotik berpotensi tinggi untuk menghambat patogen. Beberapa antibiotik yang dihasilkan diantaranya; cephamycin, chloramphenicol, kanamycin, tetracycline, spectinomycin, streptomycin, clavulanic acid, dan monensin. Naeimpoor and Mavituna (2000), menyatakan bahwa salah satu spesies dari genus Streptomyces yaitu S. coelicolor A3(2) menghasilkan undecylprodigiosin dan actinorhodin. Williamson et al. (2006), menjelaskan bahwa kedua senyawa bioaktif tersebut merupakan antibiotik yang berpigmen merah dan biru yang bersifat antimikroba, imunosupresif, dan antikanker.

Salah satu antibiotik yaitu monensin yang terisolasi dari S. cinnamonensis mampu menghambat pertumbuhan beberapa bakteri Gram positif yaitu genus Micrococcus, Bacillus, dan Staphyloccocus (Lowicki and Huczynski, 2013). Penelitian lain yang dilakukan oleh Mathur et al. (2015), melaporkan adanya senyawa antibiotik pada 3 isolat yang diisolasi dari sampel tanah di Jaipur, Rajasthan, India. Streptomyces sp. A1 (rifampin) mampu menghambat pertumbuhan E. coli ATCC 8739, P. aeruginosa ATCC 9027, Proteus vulgarius ATCC 13315, K. pneumonia ATCC 10031, dan B. subtilis ATCC 6633. Streptomyces sp. A2 (capreomycin A dan B) mampu menghambat pertumbuhan E. coli ATCC 8739, P. aeruginosa ATCC 9027, dan P. vulgarius ATCC 13315, sedangkan Streptomyces sp. A3 (clavulanic acid) mampu menghambat pertumbuhan E. coli ATCC 8739, P. aeruginosa ATCC 9027, S. aureus ATCC 6538, Aspergillus niger ATCC 16404, dan C. albicans ATCC 10231.

Tabel 1 menunjukkan hasil dari uji Minimum Inhibitory Concentration (MIC) filtrat Streptomyces sp. KCM2. Konsentrasi filtrat diturunkan dari 100\% hingga $10 \%$. Ternyata filtrat pada konsentrasi 10\% mampu menghambat sehingga konsentrasi diturunkan kembali hingga $1 \%$. Setelah diuji, diketahui bahwa MIC filtrat Streptomyces sp. KCM2 terhadap pertumbuhan MDR-A. baumannii adalah 4\% (v/v) dengan diameter hambat 8,77 mm.

Sari (2013), Mengatakan bahwa semakin rendah konsentrasi filtrat yang mampu menghambat, maka semakin tinggi aktivitas menghambat yang dimiliki oleh filtrat tersebut. Hal ini sesuai dengan pernyataan Jawetz et al. (1996), bahwa nilai MIC filtrat berbanding terbalik dengan sensitifitas mikroba yang diuji. Hasil uji ANOVA menunjukkan nilai $\mathrm{P}<0,05$ (berbeda nyata). Hal ini menunjukkan bahwa filtrat Streptomyces sp. KCM2 berpengaruh terhadap pertumbuhan MDR- A. baumannii.

MIC tigesiklin (kontrol +) memiliki zona hambat terhadap MDR-A. baumannii sebesar 21,91 mm, dan MIC filtrat Streptomyces sp. KCM2 mampu menghasilkan zona hambat sebesar 8,77 mm. Hal ini menunjukkan tigesiklin jauh bersifat lebih bakterisida karena antibiotik tersebut sudah dalam bentuk senyawa tunggal (Herawati, 2011), dibandingkan dengan filtrat Streptomyces sp. KCM2 yang masih mengandung senyawa campuran. MIC suatu filtrat dapat berbeda-beda atau sama terhadap beberapa patogen. Seperti halnya Sadhasivam et al. (2012), pada hasil penelitiannya menunjukkan perbedaan MIC dari senyawa bioaktif (AUNPs) yang diisolasi dari S. hygroscopicus terhadap beberapa patogen yaitu B. subtilis KACC 14394 (64 $\mu \mathrm{g} / \mathrm{mL})$, S. aureus KACC 13236 (32 $\mu \mathrm{g} / \mathrm{mL})$, Enterococcus faecalis KACC $13807(256 \mu \mathrm{g} / \mathrm{mL})$, Staphylococcus epidermidis KACC $13234(128 \mu \mathrm{g} / \mathrm{mL})$, E. coli KACC 10005 (32 $\mu \mathrm{g} / \mathrm{mL})$, dan $S$. typhimurium KACC $10763(32 \mu \mathrm{g} / \mathrm{mL})$. Sementara itu, Balachandran et al. (2014), melaporkan MIC dari senyawa 2,3-dihidroksi-9,10-antrakuinon yang diisolasi dari Streptomyces galbus (ERINLG-127) terhadap beberapa bakteri semuanya adalah 12,5 $\mu \mathrm{g} / \mathrm{mL}$. Bakteri yang diuji diantaranya Gram negatif ( $\mathrm{P}$. aeruginosa, $\mathrm{K}$. pneumoniae dan $S$. typhimurium) dan bakteri klinis (K. pneumoniae (ESBL-3971), K. pneumoniae (ESBL-3894) dan $S$. aureus (MRSA)).

\section{SIMPULAN}

Filtrat Streptomyces sp. KCM2 mampu menghambat pertumbuhan MDR-A. baumannii dengan besar zona hambat 23,44 mm. Minimum Inhibitory Concentration (MIC) dari filtrat Streptomyces sp. KCM2 dalam menghambat MDR-A. baumannii adalah 4\% (v/v) yaitu sebesar $8,77 \mathrm{~mm}$. 


\section{UCAPAN TERIMAKASIH}

Penulis berterimakasih kepada Dr. Dra. Retno Kawuri, M.Phil. dan Dr. Drs. A. A. Ketut Darmadi, M.Si yang telah mengarahkan dan membimbing serta Dr. Drs. Ida Bagus Gede Darmayasa, M.Si., Dr. Ni Luh Suriani, S.Si., M.Si., dan Dr. Dra. Meitini W. Proborini, M.Sc. telah memberikan saran dalam pelaksanaan penelitian dan penulisan.

\section{KEPUSTAKAAN}

Akintunde, O. G. 2014. Production of an Antibiotic-like Activity by Streptomyces sp. COUK1 under Different Growth Conditions. (Thesis).

Balachandran, C., Y. Arun, V. Duraipandiyan, S. Ignacimuthu, K. Balakrishna, and N. A. Al-Dhabi. 2014. Antimicrobial and Cytotoxicity Properties of 2,3-Dihydroxy-9,10-Anthraquinone Isolated from Streptomyces galbus (ERINLG-127). Appl. Biochem. Biotechnol. 172:3513-3528.

Barrios-Gonzalez, J., F. J. Fernandez, and A. Tomasini. 2003. Microbial Secondary Metabolites Production and Strain Improvement. Indian Journal of Biotechnology 2:322-333.

Bou, G., G. Cervero, M. A. Dominguez, C. Quereda, and J. Martinez-Beltran. 2000. Characterization of a Nosocomial Outbreak Caused by a Multiresistant Acinetobacter baumannii Strain with a Carbapenem-hydrolyzing Enzyme: High-Level Carbapenem Resistant in A. baumannii is not Due Solely to the Presence of Beta-lactamases. J. of Clin. Microbiol. 38:3299-3305.

Bouras, N., A. Meklat, O. Toumatia, S. Mokrane, m. D. Holzt, S. E. Strelkov, and N. Sabaoul. 2013. Bioactive Potential of a New Strain of Streptomyces sp. PP14 Isolated from Canadian Soil. African Journal of Microbiology Research 7(25):3199-3208.

Chopra, I., L. Hesse, and A. J. O'Neil. 2002. Exploiting Current Understanding of Antibiotic Action for Discovery of New Drugs. J. of App. Microbiol. Symp. Supplt. 92:4-15.

Cucuwaningsih, V. Wiwing, and N. P. H. Lugito. 2015. Antimicrobial Susceptibility of Multidrug-Resistant Acinetobacter baumanii in a Teaching Hospital: A Two-Year Observation. Open Journal of Medical Microbiology 5:85-89.

Herawati, F. 2011. Tigesiklin : Antibiotik Glisiklin Pertama. Medikamen (16). ISSN 1411-8750.

Howard, A., M. O. Donoghue, A. Feeney, and R. D. Sleator. 2010. Acinetobacter baumannii: an Emerging Opportunistic Pathogen. Virulence 3:243-250.

Jawetz, E., J. L. Melnick dan E. A. Adelberg. 1996. Mikrobiologi Kedokteran. Cetakan Pertama. Edisi ke-20. Penerjemah: Dr. Edi Nugroho dan R.F. Maulang. Penerbit Buku Kedokteran EGC. Jakarta.

Kawuri, R. 2012. Pemanfaatan Streptomyces thermocarboxydus untuk Mengendalikan Penyakit Busuk Daun
Pada Lidah Buaya (Alloe barbadensis Mill.) di Bali. (Disertasi). Universitas Udayana, Bali.

Lertcanawanichakul, M., K. Pondet, and J. Kwantep. 2015. In Vitro Antimicrobial and Antioxidant Activities of Bioactive Compounds (Secondary Metabolites) Extracted from Streptomyces lydicus A2. Journal of Applied Pharmaceutical Science 5(02):017-021.

Losiani, N. K., R. Kawuri, A. A. K. Darmadi. 2016. Potential of Streptomyces sp. on Plants Zingiberaceae Rhizosphere in Inhibiting Multidrug Resistant Acinetobacter baumannii. Proceeding and Enchancing Academic Collaboration Throught ASEA-UNINET Scientific Meeting. ASEAN European Academic University Network and Udayana University, Bali. 15 Februari 2016. hal. 176-182.

Lowicki, D. and A. Huczyski. 2013. Structure and Antimicrobial Properties of Monensin A and its Derivatives: Summary of the Achievements. Biomed Research International 1-14.

Mathur, N., A. Paliwal, P. Sharma, and P. Bhatnagar. 2015. Characterization of Antimicrobial Compounds from Streptomyces Isolates. Journal of Chemical and Pharmaceutical Research 7(4):1-10.

Munoz, L. S., and R. A. Weinsten. 2008. Acinetobacter Infection. New England Journal of Medicine 358:12711288.

Naeimpoor, F. and F. Mavituna. 2000. Metabolic Flux Analysis in Streptomyces coelicolor under Various Nutrient Limitations. Metabol. Eng. 2(2):140-148.

Omura, S., H. Ikeda, and J. Ishikawa. 2001. Genome Sequence of an Industrial Microorganism Streptomyces avermitilis: Deducing the Ability of Producing Secondary Metabolites. Proc. Natl. Acad. Sci. 98(122):15-20.

Ramazani, A., S. Moradi, R. Sorouri, S. Javani1 and M. Garshasbi. 2013. Screening for Antibacterial Activity of Streptomyces Species Isolated from Zanjan Province, Iran. IJPCBS. 3(2):342-349.

Sadhasivam, S. P. Shanmugam, M. Veerapandian, R. Subbiah, and K. Yun. 2012. Biogenic Synthesis of Multidimensional Gold Nanoparticles Assisted by Streptomyces hygroscopicus and its Electrochemical and Antibacterial Properties. Biometals. 25:351-360.

Saga, T. and K. Yamaguchi. 2009. History of Antimicrobial Agents and Resistant Bacteria. J. M. A. J. 52(2):15-21.

Sari, D. M. 2013. Skrining dan Isolasi Senyawa Aktif Antibakteri dari Isolat Aktinomisetes Indigenus Indonesia. (Skripsi).

Susilowati, D. N., D. Ratih, Hastuti, dan E. Yuniarti. 2007. Isolasi dan Karakterisasi Aktinomisetes Penghasil Antibakteri Enteropatogen Escherichia coli K1.1, Pseudomonas pseudomallei 02 05, dan Listeria monocytogenes 5407. AgroBiogen. 3(1):15-23

Williamson, N. R., P. C. Fineran, F. J. Leeper, and G. P. C. Salmond. 2006. The Biosynthesis and Regulation of Bacterial Prodiginines. Nat. Rev. Microbiol. 4(12):887-899. 